\title{
Curvularia Leaf Spots of Yams (Dioscorea spp.) ${ }^{1}$
}

\author{
Ramón I. Torres-López, Julia S. Mignucci, Clemens de Kok and \\ Héctor Saneaux ${ }^{2}$ \\ ABSTAACT
}

Leaf spots caused by Curvularia geniculata, $\mathbf{C}$. eragrostidis and $\mathbf{C}$. sp. were found and identified on Dioscorea rotundata and $D$, alata yams in Puerto Rico. In pathogenicity tests and field trials, $C$. eragrostidis caused more lesions than either C. geniculata or C. sp. C. geniculata and C. eragrostidis caused round to oval spots with irregular margins $(3 \times 3 \mathrm{~mm})$ scattered on yam foliage. $C$. sp. caused blotches $(42 \times 27 \mathrm{~mm})$ on leat margins. C. geniculata spores are lalcate with five cells measuring $18 \times 8 \mu(\mathrm{min}), 27 \times 14 \mu$ (max), and $25.3 \times$ $11.1 \mu$ (mean); those of $C$. eragrostidis are oval with four cells and measured $18 \times 11 \mu$ (min), $37 \times 20 \mu$ (max) and $26.1 \times 15.4 \mu$ (mean); and those of $C$. sp. spores are oval to round with four cells measuring $20 \times 9 \mu(\min ), 24 \times 11$ $\mu$ (max) and $21.9 \times 9.8 \mu$ (mean). In field trials, the $D$. rolundata cultivars Guinea Blanco and Guinea Negro and the $D$. alata yams Florido, Binugas, Forastero and Purmay were found susceptible, whereas Gemelos, Gunung, Kinampay and Moresby were resistant to Curvularia leaf spots. Curvularia spp. were found to be tuber borne, infecting both cortex and internal lissues. In Guinea Blanco cultivar more than half of the plants were infected 240 days after planting, with a maximum foliar necrosis of $31 \%$.

\section{INTRODUCTION}

Recently, the importance of yam diseases has been intensively studied $(4,5)$. Traditionally, only virus and anthracnose, also known as "candelilla," were considered serious foliar diseases of yams $(6,7)$. During the 1980-81 growing season, a high incidence of Curvularia leaf spots was observed (9) on D. rotundata cv. Guinea Blanco plants approaching senescence. In 1982 a severe leaf-spotting appeared early during tuber bulking, and leaf lesion outbreaks were observed at high severity in yam plantations distributed throughout the east west central slopes.

Leaf spots by Curvularia eragrostidis on $D$. alata yam have been reported in India (2), Hong Kong (3), and recently (1980) in Guadeloupe, French West Indies (8). Curvularia leaf spots have not previously been reported from yams in Puerto Rico. This paper covers the host susceptibility, etiology and symptomatology of Curvularia leaf spots on yams in Puerto Rico.

The true yam (Dioscorea spp.) is an important food crop of high market value in Puerto Rico, the Caribbean, Polynesian and African countries. In Puerto Rico, yams are usually planted on the humid mountain slopes

\footnotetext{
${ }^{1}$ Manuscript submitted to Editorial Board November 25, 1985.

${ }^{2}$ Research Assistant, Associate Phytopathologist, Graduate Research Assistants, respectively. Crop Protection Department, College of Agricultural Sciences, Mayagüez, P.R. 00708 .
} 
on small farms of 1 to 3 acres (4). In 1982, sales at the local markets contributed $\$ 4.9$ million to the Island's economy (1).

\section{MATERIALS AND METHODS}

\section{SURVEY AND SAMPLING}

Leaves and vines showing characteristic leaf spots were collected from yam plantations in the municipalities of Corozal, Barranquitas, Mayagüez, San Sebastián and Caguas. At Mayagüez, a disease and pest nursery was established, and yam cultivars, Gemelos, Gunung, Forastero, Kinampay, Moresby, Binugas, Purmay, Florido, Guinea and Guinea Negro, were evaluated for leaf spots. Collected leaf samples were kept in an insulated box in plastic bags and brought to the laboratory for routine isolation and bioassay. Leaf spots were removed with a cork borer. Samples were disinfected in a $0.5 \%$ sodium hypochloride solution for 4 min. and then placed in a sterile moist chamber. The moist chambers were large petri plates $(15 \mathrm{~cm})$ with wet cellulose pads. These were incubated at $28^{\circ} \mathrm{C}, 90 \% \mathrm{RH}$ with a photoperiod of $12 \mathrm{~h}$ of artificial light for $64 \mathrm{~h}$. Other leaves and vines with spots were pressed and dried for future reference. Symptom descriptions and lesion dimensions were taken from fresh material.

To make pure culture isolates, we disinfected necrotic tissue as previously described and placed it on potato dextrose agar (PDA). Plates were incubated in the dark at $28^{\circ} \mathrm{C}$. After 4 days, fungal colonies were purified by hyphal tip transfers to fresh PDA. Pure cultures were sent to the Commonwealth Mycological Institute in Surrey, England, for identification. The growth, appearance, and spore characteristies were described from pure cultures. Pure cultures were also used in completing Koch's postulates and other inoculations.

\section{INOCULUM PRODUCTION AND APPLICATION}

We used six-day-old pure cultures of each fungus grown on PDA to prepare the inoculum. Two plates each were blended with 1 liter of distilled water in an electric blender, previously disinfected with $0.5 \%$ sodium hypochloride, ethanol and then rinsed twice with sterile water under aseptic conditions. The inoculum suspension was applied to test plants and to detached leaves with a sterile atomizer bottle.

\section{PATHOGENICITY TESTS}

Two tests were conducted on whole plants in a shade house. In the first we inoculated six 5-month-old healthy plants of Guinea by spraying the foliage with the inoculum. Two plants, sprayed with a solution of 
PDA served as check. Plants were covered with plastic bags and incubated for $48 \mathrm{~h}$ in the shade house at $31^{\circ} \mathrm{C}$. Daily observations were made to record symptom development.

The second test consisted on inoculating plants of Guinea and Guinea Negro of different ages under the same conditions in the shade house since it was noticed that the disease occurred on plants approaching senescence. Groups of four plants each of the following ages were inoculated as previously described: newly emerged vines; 5 -month-old, and 9month-old plants. Two plants of each age group per cultivar served as checks.

A third test was conducted with detached leaves in vitro. Healthy leaves from Guinea and Guinea Negro cultivars were detached and surface disinfected with $0.5 \% \mathrm{NaOCl}$ solution for $4 \mathrm{~min}$ and rinsed under tap water for $20 \mathrm{~min}$. We tested five treatments in which individual groups of three surface-sterilized leaves from each cultivar were placed in separate sterilized humid chambers for inoculation. The inoculated organisms were Curvularia geniculata, C. eragrostidis, C. sp, a mixture of the three species, and a check (inoculated with a sterile agar solution). Plates were incubated at $28^{\circ} \mathrm{C}$ with $90 \% \mathrm{RH}$ for a 12 -h photoperiod.

A similar test was performed simultaneously with three whole intact plants per treatment of the same cultivars. These plants were incubated in a glass house at $33^{\circ} \mathrm{C}$ and $85 \% \mathrm{RH}$ under diffuse light. A sprinkle system provided $10 \mathrm{~s}$ of mist every 6 min for a period of $4 \mathrm{~h}$ per day. Observations on both tests were made $3,6,10$ and 15 days after inoculation.

\section{ISOLATION OF FUNGI FROM TURERS}

Tuber and tuber-seed pieces that were either treated ${ }^{3}$ or not treated with Mertect $340 \mathrm{~F}$ (thiabendazole) before storage and/or before planting were bioassayed for microorganisms. Both the storage parenchyma and the cortex tissues of Guinea and Guinea Negro tubers were examined. In another examination only the cortex from cultivars Florido (D. alata) and Guinea Blanco were bioassayed. In all cases, the corresponding tissues were surface disinfected by submersion in a solution of $0.5 \%$ $\mathrm{Ca}(\mathrm{OCl})_{2}$. These were plated on PDA and incubated at $28^{\circ} \mathrm{C}$ for 5 to 7 days, at which time organisms isolated from the tissues were identified.

\section{DISEASE DEVELOPMENT}

Plants of Florido and Guinea yams were monitored for Curvularia leaf spots in replicated plots at the College of Agriculture Farm, Mayaguez

\footnotetext{
${ }^{3}$ Tubers and seed-pieces treated with fungicide were submerged for $1 \mathrm{~h}$ in a $2000 \mathrm{p} / \mathrm{m}$ a.i. solution of the fungicide.
} 
Campus. Plots consisted of 4 rows, 20 plants/row, replicated four times for each variety. Examinations were conducted from 90 to 240 days after planting. Incidence was determined by counting the number of plants per row having Curvularia spots. Severity was determined visually by estimating the percentage per plot of foliage with spots.

\section{EVALUATION OF CULTIVARS}

A disease and pest nursery consisting of 10 yam cultivars was established with 4-row plots of 20 plants each, replicated four times. The following D. alata cultivars: Binugas, Florido, Forastero, Gemelos, Gunung, Kinampay, Moresby and Purmay, and of $D$. rotundata, Guinea Blanco and Guinea Negro, were evaluated. Diseases were assessed monthly determining the incidence and severity of Curvularia leaf spots.

\section{RESULTS}

Two types of lesions were caused by Curvularia spp. on yams in Puerto Rico (fig. 1). The most prevalent lesions were round to oval with irregular borders, sometimes with a yellow halo. Their mean size is $3 \times 3 \mathrm{~mm}$ and their color brown to black. C. eragrostidis and C. geniculata caused this type of lesions (table 1). The species were identified by Dr. A. Sivanessan of the Commonwealth Mycological Institute. Other lesions were irregular, brown necrotic blotches measuring $42 \times 27 \mathrm{~mm}$ and located on leaf margins (table 1). A different unidentified $C$. sp. caused these symptoms. All three species of Curvularia were found to be pathogenic to yams in laboratory and greenhouse tests. Symptoms associated with each were reproduced and Koch's postulates completed.

Lesions developed 3 days after inoculation on detached leaves and at 6 days after inoculation on attached leaves (table 2). Inoculations of detached leaves resulted on more spots per leaf than were found on attached inoculated leaves. This was the trend found for all three fungi with either a single or mixed inoculations. Chlorotic halos were found only on leaves inoculated with $C$. eragrostidis and with a mixture of species (table 1). Symptoms occurred earlier and more severe with $C$. eragrostidis than with the other two Curvularia species.

In both yam species, $D$. rotundata and $D$. alata, Curvularia spp. were found to be tuber borne (tables 3 and 4 ). Isolates were obtained from the cortex and the storage parenchyma tissues of treated and nontreated tubers and seed pieces of $D$. rotundata yams. No information is available regarding detection of Curvularia in the storage parenchyma of $D$. alata cv Florido. There was a lower incidence in the Florido and Guinea Negro cultivars when yams were treated with the fungicide, but not in cultivar Guinea, in which a higher incidence was detected. It is known that porosporic dematiaceous hyphomycetes such as Curvularia are not controlled by benzimadazole fungicides. 


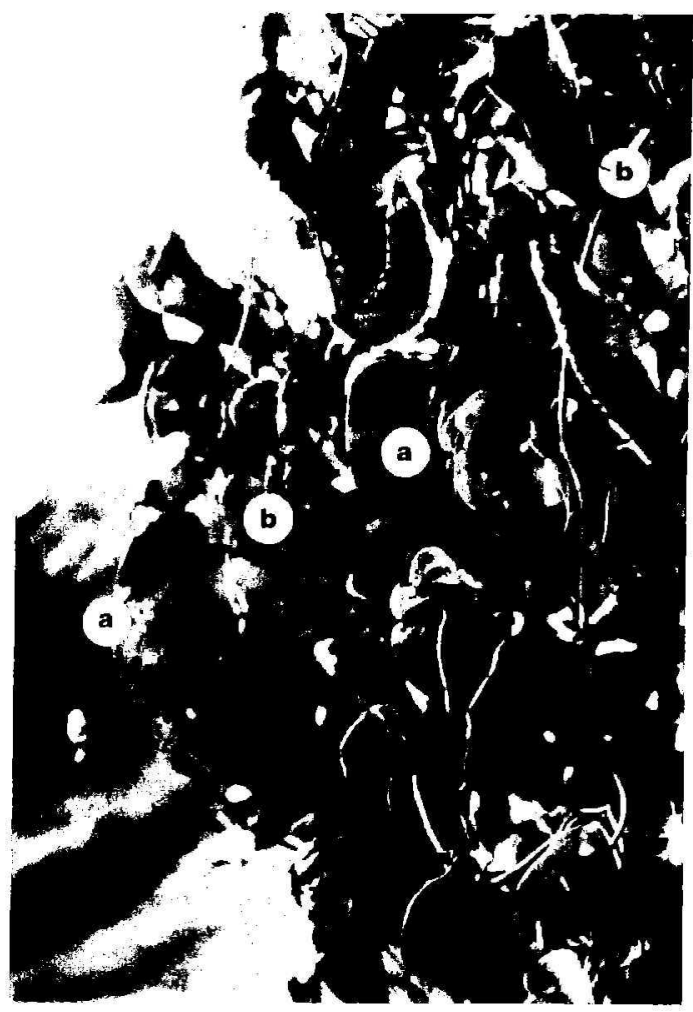

F1G, 1.-Foliage of Dioscorea rotundata plant with a high severity of leaf spots caused by Curvularia eragrostidis (ce), C. geniculata (cg) and C. sp. (c). Notice: a) The round to oval lesions caused by $\mathrm{Ce}$ and $\mathrm{Cg}$ : $\mathrm{b}$ ) the blotches caused by another species of Curvularia (c).

The first leaf spots were detected on Guinea 90 days after planting ( $1.5 \%$ severity) in the field. Incidence ranged from 4 to 8 plants per plot. At 150 days, about half of the plants of both Guinea and Florido had the disease ranging from 48 to 57 plants/plot. At that time severity range was 1.0 to $6.2 \%$ of the foliage. At 240 days, susceptibility differences between $D$. alata cv Florido and $D$. rotundata cv Guinea were evident (table 5) Severity was 8 times higher for Guinea than for Florido. In Guinea it ranged from 5.8 to $31.3 \%$, whereas Florido had only 1.3 to $3.8 \%$ of the foliage with Curvularia spots. 
TABLE 1.-Description of species of Curvularia and the symptoms they cause on yam leaves

\begin{tabular}{|c|c|c|c|c|c|c|}
\hline \multirow{3}{*}{ Fungus species } & \multicolumn{4}{|c|}{ Spores } & \multirow{3}{*}{ Colony appearance on PDA } & \multirow{3}{*}{ Type of lesions on leaves } \\
\hline & \multirow{2}{*}{ Description } & \multicolumn{3}{|c|}{ Length $x$ width $(\mu)$} & & \\
\hline & & Min & $\operatorname{Max}$ & Mean & & \\
\hline C. eragrostidis & 4 cells, ovoid & $18 \times 11$ & $37 \times 20$ & $26.1 \times 15.4$ & $\begin{array}{l}\text { Black mycelium, ad- } \\
\text { heres to the substrate, } \\
\text { velvet appearance. } \\
\text { Rapid growth. }\end{array}$ & $\begin{array}{l}\text { Dark brown to black, } \\
\text { round to oval spots, } \\
\text { sometimes with a yel- } \\
\text { low halo. ( } 3 \times 3 \mathrm{~mm} \text { ). }\end{array}$ \\
\hline C. geniculato & $\begin{array}{l}5 \text { cells, fal- } \\
\text { cate shape }\end{array}$ & $18 \times 8$ & $37 \times 14$ & $25.3 \times 11.1$ & $\begin{array}{l}\text { Black mycelium with } \\
\text { lighter sectors, cot- } \\
\text { tony fluffy colony. } \\
\text { Slow growth. }\end{array}$ & $\begin{array}{l}\text { Same as for C. eragrosti- } \\
\text { dis without halo. }\end{array}$ \\
\hline C. sp. & 4 cells & $20 \times 9$ & $24 \times 11$ & $21.9 \times 9.8$ & Black mycelium, fluffy. & $\begin{array}{l}\text { Brown irregular blotches } \\
(42 \times 2.7 \mathrm{~mm}) \text { with ir- } \\
\text { regular margins usu- } \\
\text { ally at leaf margin. }\end{array}$ \\
\hline
\end{tabular}


J. Agric. Univ. P.R. voL. 70, NO. 4, OCTOBER, 1986

TAвLE 2.--Leaf lesion incidence on attached and detached leaves of two cultivars of Dioscorea rotundata inoculated with 3 species of Curvularia

\begin{tabular}{|c|c|c|c|c|c|c|c|c|c|}
\hline \multirow{3}{*}{ Yam cultivar } & \multirow{3}{*}{ Inoculum treatment } & \multicolumn{8}{|c|}{ Mean lesions (no.)/leaf } \\
\hline & & \multicolumn{4}{|c|}{ Altached leaves } & \multicolumn{4}{|c|}{ Detached leaves } \\
\hline & & $3^{\prime}$ & 6 & 10 & 15 & 3 & 6 & 10 & $\mathbf{1 5}$ \\
\hline \multirow[t]{5}{*}{ Guinea } & C. geniculata & 0 & 0 & 1 & 3 & 0 & 2 & 4 & 4 \\
\hline & C. eragrostidis & 0 & 1 & 2 & 4 & 2 & 3 & 4 & 6 \\
\hline & C. sp. & 0 & 0 & 2 & 2 & 0 & 1 & 3 & 3 \\
\hline & Species mixture & 0 & 1 & 3 & 4 & 3 & 4 & 5 & 6 \\
\hline & Check & 0 & 0 & 0 & 0 & 0 & 0 & 0 & 0 \\
\hline \multirow[t]{5}{*}{ Guinea Negro } & C. geniculata & 0 & 0 & 2 & 3 & 0 & 2 & 4 & 5 \\
\hline & C. eragrostidis & 0 & 2 & 2 & 4 & 3 & 5 & 6 & 8 \\
\hline & C. sp. & 0 & 0 & 1 & 2 & 0 & 1 & 2 & 3 \\
\hline & Species mixture & 0 & 0 & 2 & 3 & 4 & 4 & 5 & 6 \\
\hline & Check & 0 & 0 & 0 & 0 & 0 & 0 & 0 & 0 \\
\hline
\end{tabular}

'Days after inoculation.

TABLE 3.-Isolation of Curvularia spp. from fungicide-treated and non-treated tubers in D. rotundata yams

\begin{tabular}{cllc}
$\begin{array}{c}\text { Preplant } \\
\begin{array}{c}\text { seed pieces } \\
\text { treatment }\end{array}\end{array}$ & $\begin{array}{c}\text { Tuber } \\
\text { tissue }\end{array}$ & \multicolumn{2}{c}{ D. rotundato cuttivars } \\
\cline { 3 - 4 } & Guiner & Guinen Negro \\
\hline Thiabendazole & Internal & $37.5^{2}$ & 15.0 \\
No Fungicide & Internal & 18.0 & 20.0 \\
Thiabendazole & Cortex & 20.0 & 8.0 \\
No Fungicide & Cortex & 5.0 & 16.0 \\
\hline
\end{tabular}

1 Yam seed pieces were submerged for $1 \mathrm{~h}$ in a $2000 \mathrm{p} / \mathrm{m}$ a.i. thiabendazole (Mertect 340 F) 7 days prior to bioassaying for microorganisms.

${ }^{2}$ Percentage of isolates.

TABLE 4.-Isolation of Curvularia spp. from the cortex of tuber seed pieces of D. rotundata and D. alata treated with combination of pre-storage and preplant fungicide treatments

\begin{tabular}{|c|c|c|c|}
\hline \multicolumn{2}{|c|}{ 'Time of application' of fungicide } & \multicolumn{2}{|c|}{$\begin{array}{c}\text { Incidence of Curvularia (\%) } \\
\text { on cortex tissue }\end{array}$} \\
\hline Pre-storage & Preplant & Guiner & Florido \\
\hline+ & + & 8.0 & 4.0 \\
\hline+ & - & 7.0 & 0.0 \\
\hline- & + & 5.0 & 4.0 \\
\hline- & - & 3.0 & 11.0 \\
\hline
\end{tabular}

\footnotetext{
' At pre-storage, whole tubers were immersed in a thiabendazole $(2000 \mathrm{p} / \mathrm{m})$ bath for 1 $\mathrm{h}$ and stored for 44 days. Preplant fungicide at the same rate was applied to the corresponding seed pieces 5 days before bioassaying. Twenty-five pieces were obtained from 5 different yam tuber seed pieces per treatment and plated on PDA after surface disinfection.
} 
TABIE 5.- Severily of Curvularia leaf spots on D. alata and D. rotundata yams during 1983-84 growing season

\begin{tabular}{cccc}
\hline \multirow{2}{*}{$\begin{array}{c}\text { Experimental } \\
\text { plot number }\end{array}$} & $\begin{array}{c}\text { Foliar' } \\
\text { sprays }\end{array}$ & $\begin{array}{c}\text { Severity }(\%)^{2} \\
(D . \text { olato })\end{array}$ & $\begin{array}{c}\text { Guinea } \\
(D . \text { rolundata })\end{array}$ \\
\hline 1 & + & 1.5 & 22.5 \\
2 & + & 2.8 & 20.0 \\
3 & + & 2.3 & 11.5 \\
4 & + & 2.0 & 21.3 \\
5 & + & 2.8 & 12.5 \\
6 & + & 1.8 & 10.0 \\
7 & + & 2.8 & 14.3 \\
8 & + & 2.8 & 11.3 \\
9 & + & 3.8 & 22.5 \\
10 & + & 1.3 & 12.5 \\
11 & + & 2.0 & 9.3 \\
12 & + & 1.8 & 15.5 \\
13 & + & 2.0 & 31.3 \\
14 & + & 2.8 & 20.0 \\
15 & + & 2.8 & 18.3 \\
16 & + & 3.5 & 5.8 \\
Mean & + & 2.4 & 16.2 \\
\hline
\end{tabular}

' Foliar sprays with thiabendazole were applied 216, 233, 275 days after planting at $2 \mathrm{~g}$ a.i./L to control yam anthracnose (Colletotrichum gloeosporioides).

${ }^{2}$ Severily was determined visually by estimating the percentage of foliage with spots. Mean of four replications of 20 plants each 240 days after planting.

Among the $D$. rotundata cultivars examined at the disease and pest nursery plots, as well as on farms, Guinea Negro was observed to be more severely affected by the disease than Guinea. However, in the pathogenicity tests these differences were not as obvious. In the nursery, some cultivars of $D$. alata such as Florido, Bonugas, Purmay and Forastero were found to be susceptible, whereas Gemelos, Gunung, Kinampay and Moresby showed resistance to the disease.

\section{DISCUSSION}

A leaf spot on yams caused by C. eragrostidis was reported for the first time in the Caribbean basin in Guadeloupe in 1980. Curvularia leaf spot on yams was prevalent in commercial plantations in Puerto Rico in 1982. Three species of Curvularia causing the spots were identified and their pathogenicity determined. Differences in virulence among the three species of Curvularia were also detected. In vitro pathogenicity tests, detached leaves were more sensitive to inoculations than whole plants. To our knowledge two of the species, C. geniculata and Curvularia sp. had not been reported as leaf spot pathogens of yams. Lesions of all three 
Curvularia spp. were sometimes found on the same leaf. Moreover, Cercospora leaf spots were also present on leaves infected by Curvularia spp. These findings reveal the complex etiology of yam leaf spots. Our research has provided descriptions of the three species, which should help workers monitor foliar diseases of yams. On the basis of the prevalence and severity of the disease, a research program to develop control methods for yam leaf spot is warranted. In our studies, resistance was detected on certain D. alata varieties which could be used in areas where Curvularia leaf spot is especially damaging. Use of $D$. alata cultivars with anthracnose resistance should be considered in areas where anthracnose is damaging. Gunung and Kinampay have good combined resistance to both foliar diseases (Mignucci et al., unpublished), $D$. rotundata cultivars were generally very susceptible to Curvularia leaf spots.

Since Curvularia was found to be tuber borne, special precautions should be taken in buying tubers for seed. Research is also needed to develop a control program that could include screening of pre-plant fungicides to control the pathogen at the tuber level, combined with screening fungicides for foliar applications. This program should include the testing of varieties of different susceptibility to the fungus.

\section{RESUMEN}

Se identificó a Curvularia geniculata, $C$. eragrostidis y $C . \mathrm{sp}$. como causantes de manchas foliares en Dioscorea rotundata y $D$. alata en Puerto Rico. En pruebas de patogenicidad y de campo, las manchas causadas por $C$. eragrostidis y C. geniculata, las cuales estaban dispersas por el follaje, son de redondas a aovadas con márgenes irregulares $(3 \times 3 \mathrm{~mm})$. C. $\mathrm{sp}$. Causaba manchas grandes $(42 \times 27 \mathrm{~mm})$ usualmente en los márgenes de las hojas. Las esporas de $C$. geniculata, que miden $18 \times 8$ $\mu$ (mín), $27 \times 14 \mu$ (máx) y $25.3 \times 11.1 \mu$ en promedio, son en "forma de luna" y tienen 5 células. Las causadas por $C$. eragrostidis, que son ovaladas y tienen cuatro células, miden $18 \times 11 \mu$ (mín), $37 \times 20 \mu$ (máx) y $26.1 \times 15.4 \mu$ en promedio; y las de $C$. sp., que son de ovaladas a redondeadas y tienen 4 células, miden $20 \times 9 \mu$ (mín), $24 \times 11 \mu$ (máx) y $21.9 \times 9.8 \mu$ en promedio. En pruebas de campo resultaron susceptibles a Curvularia las cultivares Guinea y Guinea Negro (D. rotundata) y Florido, Binugas, Forastero y Purmay ( $D$, alata). Gemelos, Gunung, Kinampay y Moresby (D. alata) mostraron resistencia a la mancha foliar causada por Curvularia. Curvularia spp se aisló de la corteza y tejido interno de tubérculos. En el ñame de Guinea ( $D$. rotundata) más de la mitad de las plantas estaban infectadas a los 240 dias de sembrados, cuando la necrosis foliar máxima alcanzó un $31 \%$. 


\section{LITERATURE CITED}

1. Anuario de Estadísticas Agrícolas de Puerto Rico, 1981-82. Departamento de Agricultura, Oficina de Estadisticas Agricolas, Santurce, Puerto Rico.

2. Borborua, A and G. Medhi, 1979. Dioscorea alata, a new host of Curvularia eragrostidis. Indian J. Mycol. Plant Pathol. 9 (2): 282.

3. Ellis, M. B., 1971. Dematiaceous Hypomycetes. Commonwealth Mycological Institute. Kew, Surrey, England.

4. Mignucci, J. S., J. Green, M. Cordero and P. R. Hepperly, 1982. Disease losses of yams (Dioscorea spp.) in Puerto Rico. Phytopathology 72: 984.

5. - - C. de Kok, M. Santiago, J. Green, P. R. Hepperly, H. Vélez and R. Torres-López, 1984. Yam (Dioscorea spp.) Management for control of tuber decay. Inter. Soc. Trop. Root Crops, Perú.

6. Montaldo, A., 1972. Cultivo de raices y tubérculos tropicales. Editorial, I.I.C.A., Perú.

7. Onwuenme, I. C., 1978. The Tropical Tuber Crops (Yams, Cassava, Sweet Potato, Cocoyams), John Wiley \& Sons, N.Y.

8. Toribio, J. A., S. Edwige and G. Jacquer, 1980. Pathology of yams in Guadeloupe: fungus diseases. Colloques de INRA, 2: 107-14.

9. Torres-López, R., J. S. Mignucci and C. Rodriguez, 1981. Evaluación de cultivares de ñames en Mayagüez y Corozal. Memorias SOPCA, Esta. Agric. Exp., Univ. P.R. 